\title{
Fluency or Accuracy - Two Different 'Colours' in Writing Assessment
}

\author{
Listyani \\ Faculty of Language and Literature \\ Satya Wacana Christian University \\ listyani@staff.uksw.edu
}

\begin{abstract}
Fluency and accuracy. These two things have victoriously won many teachers' attention at tertiary level. In the case of writing, these two remain debatable, and have always attracted many people, both lecturers' and students' attention. These language production measures have distracted many lecturers' concentration: should they be faithful to fluency of ideas, or grammatical and language accuracy in correcting students' essays? This paper tries to present the classical yet neverending dilemmatic conflicts within the area of writing assessment. This debate still remains interesting to follow. Data were gained from close observation on documents, that is, 21 students' essays and interviews with 2 students of Academic Writing in Semester II, 2015-2016. Four writing lecturers were also interviewed for their intellectual and critical opinions on these dilemmatic problems in assessing writing. Discussion results of FGD (Forum Group Discussion) involving all writing lecturers at the English Education Study Program at the Faculty of Language and Literature of Satya Wacana Christian University which were held in June, 2016, were also included as source of data. Hopefully, this paper gives a little more "colour" in the area of writing assessment, and gives a little enlightenment for other writing lecturers.
\end{abstract}

Keywords: fluency, content, accuracy, grammar, Academic Writing

\section{Introduction}

Students with average
capability usually have some problems which can still be tolerated both in the content and language of their writing. The problem lies in the writing of students with low ability or proficiency of English. Both the content and language may be very difficult to understand. This, unavoidably, can frustrate the teacher. Perfect language with poor ideas is not enough. However, how can ideas be understood if the language as a means to convey the intended meaning is too difficult to grasp? A student may have bright ideas, but without good language, those ideas will be in vain; they will not be conveyed properly to the readers (read: teachers). The teacher then may end up giving an emotional comment on a certain student's paper: "What did you intend to say, actually?" written in red ink with big letters. It is indeed a dilemma for teachers; they may be confused, which one to value more? Student's ideas or language? It is not an easy question to answer.

One central question to be answered in this paper is: Which one should be prioritized in assessing writing, grammar or content? In this 
paper, I want to argue that both the content and language in a piece of writing are to be given attention in assessment, though there may be hierarchy in the scale. The content, as well as the accuracy of language, should not be passed unnoticed by the teacher. Some data taken from some students' journals will be attached as a support for my argument.

\section{Research Methods}

Data for this study were mainly derived from direct interview four lecturers and two students, whom I named Lecturer A, B, C, and $\mathrm{D}$ according to the time of the interviews (in chronological order). Student A and Student B. Besides that, close observation was also done on the students' essays. Discussion results of Forum Group Discussion with Academic Writing Lecturers were also used as source of data. The data were then qualitatively analyzed and interpreted.

\section{Grammatical Accuracy or Content?}

Elbow (1998, p. 299), an expert in writing who is for fluency in writing, mentions that most people's writing does not have "voice" because people often stop in the middle of the sentence and think about which word to use or which direction they should go. Writing with "voice", according to Elbow, is "Writing into which someone has breathed". It has the fluency, rhythm, and "liveness" that exist naturally in the speech of most people when they are enjoying a conversation. People who write frequently, copiously, and confidently will be successful to get voice into their writing. Writing with real voice, Elbow further explains, has the power to make you pay attention and understand; the words go deep. Writing without voice, in his opinion, is "wooden and dead" because it lacks sound, energy, and individuality.

At tertiary level, whether they realize it or not, students are usually preoccupied with accuracy, and many do not write in English beyond sentence level when entering university. Students are typically not familiar with process approaches in writing or with the requirement of writing a research report (Reichelt, 2009). Hirose (2001), in Reichelt (2009, p. 198), indicates that for the first-year English majors in her classes, "fluency-aimed writing activities" besides activities that raise students' awareness of conventions in academic writing, are important. This is because students still have little experience of composing in English.

Other researchers, Schoonen, et.al. (2009, p. 80) argue that when it comes to formulating a message, linguistic skills and knowledge become prominent in the writing process. They further mention that for sure, the writer needs to have a larger "repertoire of words, collocations, sentence frames, and morphological options" to get the intended message across. In order to formulate fluency in writing, the retrieval of words, collocations, and sentence frames should be easy and should not burden students' working memory. The underlying reason is because memory resources should be available for "keeping tracks of the discourse". The need for linguistic 
proficiency and metacognitive knowledge is higher than the ones needed for speaking. In Schoonen et al's opinion, "lack of context and conversational feedback" demands a higher level of explicitness. In FL writing, things become more difficult. Limited linguistic knowledge of FL can hinder the use of metacognitive knowledge and writing experience.

Schoonen et al $(2009$, p.82) further claim that L1 expertise and knowledge comes under pressure at other stages of the writing process, that is, during formulation, when the writer is struggling with the difficulties caused by limited FL linguistic knowledge. Writing is much slower and cyclical than speaking. They confirm that "The relationship between $L 1$ and $F L$ writing proficiency is without doubt mediated by FL linguistic knowledge, but the issue of how and to what extent these three constructs interest is still not settled." Schoonen et al show the correlations between linguistic knowledge and writing performance, and between fluency and writing performance are generally higher than for the mother tongue.

The more metacognitive and linguistic knowledge a writer has, the faster the grammatical and lexical knowledge can be retrieved, and the better the writing performance will be (Schoonen et al, 2009, p. 83). Schoonen et al also mention that. foreign langauge writing is more dependent on the level of linguistic knowledge and fluency, rather than first language (L1) writing. Foreign or second language writing is generally higher for English than for the mother tongue. From two examples of writing texts of two students, Schoonen et al found in their research that Student A performed poorly on English grammar test and received low grades for his/ her test and the writing. On the other hand, Student B scored highly on both grammar test and writing assignment. There is a great difference on grammar repertoire on students of the same class (Schoonen et al, 2009, p.85).

Another opinion comes from Raimes (2002) who states that in the early 1960's, writing courses were also treated as grammar practice. Later on, it was realized that writing was generative of ideas; it was tolerable to be messy and chaotic in the process. Raimes (2002) then sums up that teachers must accept the messy and chaotic nature of writing, or, if teachers do not like the "mess," they can impose order on it to focus on grammar, rhetorical modes, and models of academic discourse. This is intended to provide teachers themselves with neat systems of teaching. To focus on both content and language is, unavoidably, an extra work on the teachers; more time to give feedback and comments on both aspects (p. 309). This is in line with Penaflorida (2002)'s opinion that:

Teacher gives writing assignments which take time to mark and give feedback to students, or worse, teacher sometimes fails to return the papers. We were students once and know how important the teacher's feedback was (p.345). 
Ur (1999) also raises this question, "What should feedback be mainly on: language? Content? Organization?" She then answers that the hierarchy should be content first, whether the ideas written are significant and interesting, then organization - whether the ideas are arranged in good and pleasing way and lastly language forms, whether the grammar, vocabulary, spelling and punctuation are acceptable in terms of the standard accuracy (p.170).

Sokolik (2003) also gives an idea of what aspects to be assessed in writing; she asks teachers to ask themselves, what aspects to assess: creativity or originality of ideas, writing format, grammatical accuracy, inclusion of recently taught material, or spelling and punctuation. In short, just as Ur's opinion, there are three aspects to assess: content, organization and grammar (p.94). Basically, those three aspects are to be given attention in assessing a piece of reading journal: content, organization and language.

From the discussion above, I can say that it remains debatable, which one should teacher give emphasis on the assessment of a piece of writing: the content or the grammatical accuracy, or both? Well, many argue that it is the content that becomes the primary concern of writing. As long as students can express their ideas well (clearly), then the piece of writing is considered okay, regardless of the language problems he/she may encounter. I personally prefer seeing a piece of writing from both the content or fluency and language accuracy. Dollahite and Haun (2012) firmly state that a writer's goal is to make sure that they have presented their ideas well to the readers, so that those ideas can be clear to them. Dollahite and Haun (p. 100) further claim, "Your job is to create a reader-friendly paper that smoothly guides the reader from one idea to the next."

As mentioned before, without understandable language, brilliant ideas will not be understood by the readers (read: teachers). Sokolik (2003) and Ur (1999) have great ideas in saying that in writing, the priority is the content, but it does not stop there; there are still other aspects to consider which are no less important than the first ones: organization of ideas and language accuracy. The biggest percentage may be given in content, but still organization and language must be given a place in the assessment, for the last two also take part in making a piece of writing understood by its target readers. As concluding remarks, I believe that every lecturer has their own beliefs and perceptions. The same case happens in this matter. Some lecturers prefer giving more emphasis on grammar or accuracy rather than content or fluency. Other lecturers would do the other way around. No one is right and no one is wrong. As long as ideas can be conveyed successfully to the readers, both are okay. Whether the content or the grammar gets priority in the assessment, it will not cause a problem. Presented below are examples of students' sentences which have problems in grammatical and content levels. 
A student once wrote,

"The quotation from Mark Surman tell to people if they hardly to survive in the future if they get blind about digital functions...The informations that received by the students are more global rather than use books. The informations on web are larger than books. It happens because the digital informations are easly to distribute for entire world, it is not like books that need some regulation to distribute to another area.R.F. George assumed that "We have infinite supply of information and yet we cannot read" (source: goodreads.com,no date). It means the informations that provide by digital era are very global and many in quantity." (Student C's essay, paragraph 1 \& 5, unedited)

Though he made lots of grammatical errors in his essay, but his ideas are still understandable. The following example is a student's writing with problems in fluency which hinders understanding.

"That is simple reason why digitalization should be taught in Senior High School. It is because Senior High School students will more accept that way than elementary or Junior High student. How do come? Senior High School students, usually have been using digitalization better than other level of educations. It may because they have had further material and explanations about how to use Internet in previous level. High School students also have been mature to look for and get proper informations which they absence for." (Student D's essay, paragraph 2, unedited)

Both students came from the same academic year, they were from Batch 2014, and they were asked to write about the same topic: Digitation in secondary education. Yet, the first student's essay is more understandable than the second one. It is because, the level of errors is on the grammar, in the first student essay; while the second student had problems with her fluency.

\section{Discussion on Interview Results}

For this paper, I interviewed 4 writing lecturers These lecturers come from different universities and they range from junior to the senior ones. Below are their opinions on grammar/ accuracy or content/ fluency. I presented the results of the interviews chronologically. The table below will clarify the four lecturers whom I interviewed.

Table 1: Lecturers who were interviewed

\begin{tabular}{cccc}
\hline Initials of Lecturers & Universities & $\begin{array}{c}\text { Experiences in teaching } \\
\text { writing }\end{array}$ & Sexes \\
\hline A & $\begin{array}{c}\text { Sanata Dharma } \\
\text { University }\end{array}$ & 7 years & $\mathrm{M}$ \\
\hline B & $\begin{array}{c}\text { Satya Wacana } \\
\text { Christian University }\end{array}$ & 10 years & $\mathrm{F}$ \\
\hline C & $\begin{array}{c}\text { Satya Wacana } \\
\text { Christian University }\end{array}$ & 2 years & $\mathrm{M}$ \\
\hline D & Miami University & 17 years & $\mathrm{F}$ \\
\hline
\end{tabular}




\section{Writing Lecturers' Opinions}

Lecturer A has been teaching writing for 7 years in three different universities, Universitas Kristen Krida Wacana, Sampoerna University, and Universitas Sanata Dharma. He admitted that in teaching writing, his focus is mainly on the content of my students' essays first. Then, I look at their grammar. Similar answers came from the second respondent, that Lecturer $\mathrm{D}$, from Miami University in Ohio, USA. She also thinks that priority should go to content first, grammar ranks second.

Asked about priority, Lecturer A thinks that the content is the priority because the content contains the intended message. When his students write in Bahasa Indonesia, for example, they still have problems in the content. Therefore, if we can teach/assist the students to develop the content, their skills on idea development will be transferable when they write in any languages. Talking about students whose sentence forms are very simple, like S V O pattern, Lecturer A mentioned that it happened in his class as well, "I think those students should be trained to think critically. As a result, their ideas are not superficial. And, for those students having good ideas but poor grammar, we should assist them to express their ideas in good English". Lecturer A then suggests that writing lecturers need to focus on the fluency first (the development of ideas), accuracy later. The underlying reason is if we only focus on the accuracy, we will be trapped in grammar-oriented writing. As a result, we teach grammar, instead of writing.

Different perspectives come from Lecturer B, who has been teaching writing for about 10 years. She was teaching Writing 3 and 4, and at present Expository and Argumentative writing, and Academic Writing. She focuses on the content, rather than grammar. For her, content - including organization of idea, coherence - is more important than grammar, because writing is not only about grammar. She further states, "Although grammar is important, but to me it is only one of the components that supports writing. Not the heart of the writing process. Writing is about sharing or expressing our thoughts. We might have perfect grammar. But it will be meaningless, if we don't have enough idea to write on our draft. Mastery in writing is not only about grammar mastery".

Lecturer B further states that there is no guarantee that the students who can perfectly write simple sentences can have good idea on the topic they write. Also, in terms of style, if the students keep using simple sentences, it will make the writing style boring and monotonous. Although their grammar might be perfect. It will be obvious because they only use simple sentences. So, their mistake will be very limited.

Lecturer B prefers to prioritize on fluency. She also suggests that integrating writing with reading is a perfect idea as it might be able to cater both fluency and accuracy. By using the reading texts as the models, the students might be aware of the author's writing styles. They can also have more ideas about 
the topic. They can also be exposed with the grammar and vocabulary for their own writing.

Different from the previous two Lecturers, Lecturer $\mathrm{C}$, who has just been teaching writing for 2 years, Creative Writing, Argumentative Writing, and Academic Writing, always believes that good grammar can help him understand essays better. In the Creative and Argumentative Writing, he pays attention to the grammar a lot since, for him it is a "foundation" class before entering classes in their upper semesters. "If their grammar is still bad, I will feel sorry for it. I discuss their mistakes almost every week; I remind them to use an article for a singular countable noun, for instance. However, in Academic Writing, I usually focus on their content; seeing their outline; coherence among paragraphs in the first five weeks though I become stricter with their grammar after they submit their first draft".

Asked about which one should be prioritized, Lecturer $\mathrm{C}$ is certain that for undergraduate students, considering their role as a teacher' candidate, grammar is more important. These students will become a model for their future students. If they cannot write sentences using correct grammar, they will not be able to teach their future students to do so. His attention is more on ensuring the students' language accuracy after they graduate. For first year writing classes, Lecturer $\mathrm{C}$ suggests that accuracy should be give more attention because it is the "foundation" for the students before entering future writing classes. It will be nice if students can use a software to check grammatical aspects of their writing before they submit their work.

The last respondent, Lecturer $\mathrm{D}$, has been teaching writing since 1999 at the university level. She was teaching Descriptive Writing and mostly Academic Writing. Now she is teaching composition at Miami University, Ohio, The United States of America. Lecturer D states that both grammar and content should be prioritized because if we are teaching second language learners, we cannot focus on one. "Through grammar, other people can understand the content. Both are important. If we focus on the grammar, but the content is not good, then, it's just the same thing. But the way you teach it, I think you must focus on the content, and then, grammar". Asked about the percentage for grammar and content in the assessment rubrics, Lecturer D mentions that in writing assessment, both need emphasizing. Content is $70 \%$, and language or grammar is like $30 \%$. Sometimes, there are students whose content is good, but the grammar is not, so we cannot separate grammar from content. Both are important.

From my interviews with the four lecturers, a red thread can be seen. Lecturer A was in line with Lecturer B and Lecturer D. They gave priority to fluency. Lecturer $\mathrm{C}$ was the only one who preferred to focus on grammar. For him, accuracy was more important. About fluency first then accuracy, Chin et al (2013a) also suggest that writers read their draft to check content and organization, write comments on a different sheet of paper, write the 
weaknesses of their own paper and write down ways to improve it. After checking the content and organization, writers should also read the draft to check the grammatical errors and style problems. Singleton (2011) also strengthens this idea. She explains that after revising the ideas in the paragraph, a writer is ready to edit, which means to check the grammar.

Singleton further clarifies that if a writer edits the grammar first, he/she will waste his/her time working on irrelevant sentences. Smalley et al (2012, p.9) have a similar idea. They mention that editing and proofreading are the final steps in writing. Editing means checking sentences to make sure that they are all grammatically and mechanically correct. While proofreading means reading the paper again to find "any remaining errors in grammar, spelling, mechanics, or punctuation".

\section{Students' Opinions}

Besides the four lecturers, I also interviewed two students whom I thought had good mastery of grammar. From my on-line interview with two Academic Writing students, I found that both students consider grammar an important part of writing which helps readers understand their ideas. These two students always had good ideas besides very good grasp of English grammar. Student A firmly says that in writing both grammar and content are important. She explains further, "The content of our writing should be meaningful, interesting, and reach the purpose of the text. We also should make our writing understandable by using correct grammar" (Unedited). Being a daughter of an English teacher, she feels that she has more opportunities to acquire English more than others who do not have English teacher parents.

Similar to Student A, Student $B$ also thinks that grammar and content are equally important, especially in writing. She claims, "If we master the grammar well, ppl (people) will easily understand what we're going to convey (content). The use of language in writing is important because the language is a tool to make ppl understand our meaning. It's kinda a bridge to help us deliver our ideas well to the reader." (Unedited)

Talking about how she acquired good command of English, Student B said that she started to join an English course since I was at the first grade of elementary school. That time her mother asked an English tutor to come. She then I joined an English course in Salatiga when she was eight. The course has many stages, such as beginner, intermediate, and advanced. Each stage is divided into some levels also and every 4 months, she had to pass each level. When she was in grade 6 , she passed the end of the intermediate level, while her other course mates were senior high school students. These two students excelled in terms of grammatical awareness in their writing.

From my interviews with both students, who both came from 2014 academic year, a conclusion can be drawn. Both students preferred to give priority on grammar. For them, good grammar will help clarify the fluency of their 
thoughts in writing. Thus, it will help readers understand their view points. Their opinion is in line with Chin, et al (2013b, p.125)). They mention clearly, "Writing filled with errors in grammar, punctuation, selling, and capitalization is very distracting to a reader." They further assert that writers have to fix these errors before submitting the essay for evaluation.

\section{Forum Group Discussion (FGD) with Academic Writing Lecturers}

On June 24, 2016, I managed to conduct a forum group discussion with four Academic Writing Lecturers, all from Satya Wacana Christian University Salatiga. One of them was Lecturer $\mathrm{C}$ (who also became the respondent I interviewed). The table below will clarify the FGD attendees.

Table 2: FGD Attendees

\begin{tabular}{ccc}
\hline Initials of Lecturers & Experiences in teaching writing & Sexes \\
\hline $\mathbf{C}$ & 2 years & $\mathrm{M}$ \\
\hline $\mathbf{E}$ & 17 years & $\mathrm{F}$ \\
\hline $\mathbf{F}$ & 14 years & $\mathrm{M}$ \\
\hline $\mathbf{G}$ & 2 years & $\mathrm{F}$ \\
\hline
\end{tabular}

One of the topics discussed is grammar in writing. Dealing with the first problem discussed, Should grammar also be taught in writing classes? The answers are as follows. Yes, grammar should be taught in writing, but independent grammar classes are still needed, with 2 reasons. First, grammar teaching surely helps students in using grammar in context in their writing. Secondly, lecturers do not need to spend too much time on grammar.

Discussing the second question (Which one is to be the top priority for contextual grammatical aspects to be taught in writing?), all the lecturers had the same agreement. Frequency of the most frequently seen/found grammatical points that appear in writing is not the only parameter that needs consideration. The common and important ones should be taught. Talking about point 3 (Which one should be prioritized? The fluency, the accuracy, or both?) The lecturers attending the group discussion had various answers. One prefers giving equal attention to both, one lecturer to grammar. One junior lecturer mentioned that for lowerlevel writing classes, yes, grammar should be prioritized; another lecturer prefers to give priority to fluency, and the last one, content first, grammar later.

The last question is Should grammar get a better position in the rubrics? All the lecturers agreed that the percentage should be between $30-35 \%$ for grammar in the assessment rubrics in all levels of writing. This is similar to Lecturer D's opinion. The underlying reasons are as follows. First, this is to balance grammar and fluency. Secondly, grammar points can be used as an incentive. If students can write with good grammar, they will get more points in the rubrics. The next reason is grammar is an integral part of writing, and good grammar adds meaning. The last reason is if students have good fluency, but poor 
grammar, then their writing is not realistic.

Agreement was made at the end of this FGD session. There were three points. First, grammar needs to be taught, though independent grammar classes are still needed. Secondly, the most-frequently appearing grammatical items are not necessarily the ones to be taught. The next agreement is both fluency and accuracy should be given priority in writing assessment. The final agreement is that rubrics for grammar should cover $30-35 \%$ of the whole percentage of scores.

\section{Conclusion}

From the discussion part above, two conclusions can be drawn. Frist, every lecturer of writing courses has their own preference of which should be given priority. Grammar or fluency. Secondly, grammar needs to be given bigger portion in the assessment rubrics. Rubrics for grammatical points of $30-35 \%$ will be ideal for writing assessment. The rest $65-70 \%$ should be given to fluency or content.

\section{Acknowledgements}

I owe words of thanks to my respondents, Ibu Henny ZachariasLiem, Bapak Priyatno Ardi, Bapak Yustinus Calvin, and Ibu Anita Kurniawati. Also to my students Bene and Bella. A bunch of thanks are also given to Academic Writing Lecturers who attended FGD, Ibu Titik Murtisari, Pak Yustinus Calvin, Pak Christian Rudianto, and $\mathrm{Bu}$ Yustina. Thank you so much for your help.

\section{References}

Chin, Peter; Reid, Samuel; Wray, Sean; and Yamazaki, Yoko. Academic Writing Skills. Student's Book 1. (2013a). CUP.

Chin, Peter; Reid, Samuel; Wray, Sean; and Yamazaki, Yoko. Academic Writing Skills. Student's Book 3. (2013b). CUP.

Dollahite, Nancy, E \& Haun, Julie. (2012). Source Work: Academic Writing from Sources. Boston: Cengage Learning.

Elbow, Peter. 1998. Writing with Power: Techniques for Mastering the Writing Process. OUP.

Penaflorida, Andrea H. (2002). "Nontraditional Forms of Assessment and Response to Student Writing: A Step Toward Learner Autonomy." In J.C. Richards \& W.A. Renandya (Eds.). Methodology in Language Teaching. Cambridge: Cambridge University Press.

Raimes, Ann. (2002). "Ten Steps in Planning and Training Teachers of Writing". In J.C. Richards \& W.A. Renandya (Eds.). Methodology in Language Teaching. Cambridge: Cambridge University Press.

Reichelt. 2009. A Critical Evaluation of Writing Teaching Programs in Different Foreign Language Settings. In Rosa M. Manchón. Writing in Foreign Language Contexts: Learning, Teaching, and Research. Bristol: Datapage International Ltd.

Sasaki, Miyuki. 2009. "Changes in English as a Foreign Language Students' Writing over 3.5 Years: A Sociocognitive Account. In Rosa M. 
Manchón. Writing in Foreign Language Contexts: Learning, Teaching, and Research. Bristol: Datapage International Ltd.

Schoonen, Rob; Snellings Patrick; Stevenson, Marie; and Gelderen, Amos Van. 2009. "Towards a Blueprint of the Foreign Language Writer: The Linguistic and Cognitive Demands of Foreign Language Writing. In Rosa M. Manchón. Writing in Foreign Language Contexts: Learning, Teaching, and Research. Bristol: Datapage International Ltd.

Singleton, Jill. (2011). Writers at Work. The Paragraph. $11^{\text {th }}$ Printing. CUP.

Smalley, Regina L.; Ruetten, Mary K.; and Kozyrev, Joann Rishel. (2012). Refining Composition Skills. Academic Writing and Grammar. Boston; Cengage Learning.

Sokolik, Maggie. (2003). "Writing." In David Nunan (Ed.). Practical English Language Teaching. New York: The McGraw-Hill Companies.

Ur, Penny. (1999). A Course in Language Teaching. Practice and Theory. Cambridge: Cambridge University Press.

Zacharias, Henny. July 8, 2016. Personal Interview. Salatiga. 